\title{
The Role of Old Believers in the Uprising of 1863-1864 and the Belarusian Nation-Building Process in the Second Half of the 19th Century (Towards a Historical and Ethnographical Reconstruction)
}

\author{
BY \\ ULADZISLAŬ IVANOŬ*
}

The Uprising of 1863-1864 provoked not only the tsarist reaction in the Belarusian lands, but above all the nation-building processes that started here late (compared to the rest of Europe), but led to the formation of the Belarusian nation. The ethnological and historical reconstruction and analysis of ethnographic statistics of the nineteenth century relating to Belarusian Old Believers are very interesting in this regard. On the one hand, Old Believers were strangers from Russia and Muscovy, and therefore enemies of the idea of the Grand Duchy of Lithuania and committed adherents of the Russian idea. On the other hand, persecuted and driven from Muscovy, and having found refuge in the territory of Belarus, many Old Believers were integrated, even assimilated, with the Belarusians. During the Uprising of 1863-1864 not all Old Believers supported the tsarist government. Statistics, journalistic and ethnographic data from the nineteenth century illustrate the ambiguity of the role of Old Believers in Belarus. In addition, statistics and the First General Census of the Russian Empire in 1897 recorded a certain 'Belarusianization' of Old Believers, their active participation in the Belarusian nation-building process.

Fundamental changes in the role of the Old Believers in the Russian Empire took place in the 1860s. If earlier the Old Believers kept their distance and avoided contact with any authority, especially Russian, later, in part thanks to the liberalising reforms and pacifying actions of Tsar Alexander II (the abolition of serfdom, the granting of permission to Old Believers to join the guild of merchants, the official status and registration of Old Believers marriages, granting of a permit to build Old

* Uladzislaŭ Ivanoŭ - MA in Political Science, political scientist, ethnologist, lecturer in political science and political history at the European Humanities University (Vilnius, Lithuania). 
Believer churches etc.), certain communities of Old Believers (primarily fedoseevt$\left.s y^{1}\right)$ demonstrated active rapprochement with the former homeland. In its radical form it sometimes turned into edinoverstvo. ${ }^{2}$ The Tsar suddenly turned from the Antichrist into a saviour, while former allies, lords and nobles, became enemies.

However, we should point out right away that not all Old Believers participated in the rapprochement. Thus, the popovtsy ${ }^{3}$ preserved their cautiousness and neutrality, and continued to demonize the Tsar and the tsarist government. Furthermore, not all pomortsy $y^{4}$ treated the Tsar's actions favourably. They had a certain ideological conflict with the fedoseevtsy regarding issues of marriage. Attempts to impose edinoverstvo, to convert Old Believers into Orthodoxy and to ban construction of their temples until 1883, often left Old Believers hostile to the authorities and the Tsar.

One should always keep in mind that there is no single denomination of Old Believers in general, and that includes the Old Believers in Belarus. There are several quite distinct trends (pomortsy, fedoseevtsy, beglopopovtsy or popovtsy, and edinovertsy). Conflicts within these movements often hindered rapprochement and merger into a single Old Believers denomination. That is why the external observations and suppositions, that perceive Old Believers as a single current, are wrong. However, the Belarusian belles-lettres and history writings show mostly negative, hostile portrayals of the Old Believer, a Maskal: 'fifth column', 'sellers', 'betrayers of insurgents' (Jaŭmienienka 2012), 'villains' (Vaĺtar 2009, 80-82), 'aliens' (Doŭnar-Zapoĺski 1994, 222), 'the other, 'not from here'(Alieksieiev 1974, 42; Tatarinov 1999, 39-40). Our researchers often refer to secondary, very engaged and therefore questionable Russian and Belarusian scientific studies that promote the image of the Old Believer as a bearer of Russian culture and language in the service of the Tsar, the defender of 'the Russian idea' and a determined enemy of Belarusians and Poles, a 'Russian element'(Bendin 2013; Sigma). Here we are in the position of determining supposedly unquestionable notions of Russians, Belarusians, Poles, etc., while the nineteenth century Old Believers, Belarusians and Russians cannot be treated through the prism of modern understanding of nations.

1 Fedoseevtsy - a conservative Old Believers movement. It advocated celibacy, convinced of the total depravity of the Russian state, believed in the imminent coming of the Kingdom of Antichrist and refused to pray for the Tsar. In today's Belarus fedoseevtsy is almost totally assimilated into other communities of Old Believers (mainly pomortsy) or with Belarusians (author's note).

2 Edinoverstvo - an Old Believers community (other names: 'New blagoslavlentsy' and 'church old believers') that preserved the old pre-iconic religious traditions but nonetheless recognized the jurisdiction of the Moscow Patriarchate hierarchy (author's note).

3 Popovstvo is one of the two main denominations of Old Believers, which recognizes the sacrament of the priesthood, unlike bespopovtsy (author's note).

4 Pomortsy or Pomorie is one of the largest Old Believers denominations, and has no three-rank hierarchy. This means that worship and the sacraments (baptism, confession) are carried out by parishioners, that is, by the spiritual teachers (author's note). 
Ethnographic studies and ethnological reconstructions that can be carried out on the basis of ethnographic and statistical data of the nineteenth century show tendencies completely opposite to those described in belles-lettres and the press. The process of merger and assimilation of the Old Believers into the Belarusian masses can be identified prior to the Uprising of 1863-1864 and the active Belarusian nation-building process. This trajectory was followed by a section of the local Old Believers (mostly pomortsy and popovtsy) (Siementovskii 1872; Siementovskii 1864; Sapunov 1883; Nikiforovskii 1895; Marks 1995; Gorbachievskii 1895; Anikievich 1907; Potashenko 2006; Grek-Pobisova 1992; Korotkaia, Prokoshina, and Chudnikova 1992; Ivanoŭ 2008). These trends are contrary to stereotypes that simply show the Old Believer in the Belarusian lands of the nineteenth century as a 'fifth column' or 'Russian element'.

It should be pointed out that the topic of the Old Believers is often used by ideological discourses for their own purposes. The other extreme is manifested in the fact that the Belarusian historical and ethnological sciences almost completely ignore the problem: they do not integrate the topic of Old Believers within their field of interest and research. Local humanities scholars often subscribe to the Russian ethnology, which considers the Old Believers a Russian sub-ethnos (Pivnieva 2001; Bendin 2013).

Based on sociological, linguistic studies, as well as on my own ethnological studies, I tend to think that the Old Believers in Belarus had long before become the Belarusian Old Believers, and since the nineteenth century many Old Believer communities and groups have developed on the border of being Russian and Belarusian. Old Believers outside Russia, and moreover in closed communities, did not always keep their Russian nature. Therefore it cannot be stated that all Old Believers are representatives of the Russian sub-ethnos. Outside Russia, many Old Believer communities were integrated into the local population and took part in the nation-building processes of other countries (Lithuania, Poland, Belarus and others) (Pervaia 1899; Pervaia 1901; Ivanoŭ 2010; Zavarina 1986; Potashenko 2003; Potashenko 2007).

Therefore, the major point of this study is to elucidate the role of the Old Believers in the Kalinoŭski Uprising. It was ambiguous: the Old Believers were the enemies and promoters of all Russia on the one hand; and, on the other, they were apolitical, but sometimes supported fighting with the tsarist government, which had 'offended' Old Believers in the past.

This kind of inversion is described in Lithuanian (Praspaliauskiene; Potashenko 2006), French (Leclère De la; Leclère Les Vieux-Croyants; Leclère Naissance), and Russian (Dolbilov 2010), sources, but still not in Belarusian. Attention is drawn to the fact that in the first half of the nineteenth century Belarusian Old Believers 
continued to treat the Tsar as the Antichrist, but in the beginning of the second half of the century, when Alexander II came to the throne and then abolished serfdom and adopted laws in favour of Old Believers, some Old Believers, soglases ${ }^{5}$, radically changed their point of view. They began to justify the former 'Tsartorturer' and became hostile towards their former allies - the Polish-BelarusianLithuanian magnates and gentry. This topic drew little attention from Belarusian historians. Indeed, academic and journalistic writings are dominated by the idea that the tsarist government found theist agents on the lands of the former Grand Duchy of Lithuania, the Old Believers, and strangers from Muscovy, which meant the preservers of (old) Russianness.

Clashes and conflicts between the Old Believers and the rebels during the Uprising were frequent. There are many cases describing how Old Believers (mainly fedoseevtsy) turned in the insurgents and the rebels in response killed collaborating Old Believers on their farms (in Lithuania and Belarus); or the local nobility in retaliation for collaboration refused to renew rent for many Old Believers' families (west of Viciebsk province) (Briezhgo 1956; Zavarina 1986; Leclère Naissance). As a result, hundreds of families found themselves without a home. Social conflict in this way became partly national and religious. It should be pointed out that many Old Believers, as well as Belarusian peasants who caught the insurgents, actually stood against the lords and priests. It was an occasion to take revenge on the rich, the wealthy, the powerful, 'bloodsuckers' so to speak (Briezhgo 1956; Leclère Naissance). However, not all the nobility sided with the rebels. Uladzimir Vaśkoŭ in his research on Panizoŭje and Sievierščyna argued that the local nobility did not support the rebellion, and was rather demonstrating loyalty to the Tsar (Vaśkoŭ 2010, 6-9).

Nevertheless, we should not generalize or exaggerate these facts. Not all Old Believers sided with tsarism. Fedoseevtsy as the most radical group of Old Believers in the Belarusian lands ranged in their attitudes from total disregard for the former homeland to an unexpected reverence following the Tsar's concessions. These were fedoseevtsy who expressed active support for tsarism during the Uprising. Other soglases did not show the same enthusiasm.

Firstly, certain bespopovtsy and popovtsy soglasy continued to criticize the Tsar and expressed a kind of neutrality during the uprising. The knowledge of the Old Believers' soglases in Belarus in the nineteenth century leads to an accurate understanding of the overall picture of the ours versus strangers dynamic in

\footnotetext{
Soglas is a community, a sect, and denomination (mostly religious). Typically, this concept applies to the Old Believers. Historically there appeared several dozen Old Believers' soglases (popovtsy bespopovtsy; bespopovtsy are devided into a number of large and small soglases: pomortsy, fedoseevtsy, filipovtsy, netovtsy, etc.). In Belarus, the majority of Old Believers belonged to pomortsy (between 20,000 and 50,000), and popovtsy (no information available on the number) (author's note).
} 
that period of history. A large number of the Old Believers remained neutral in as big a social conflict as the 1863 Uprising. On the one hand, we are dealing with 'fedoseevtsy's betrayal' when certain soglases of Old Believers changed their ideological orientation and took the side of the Tsar; on the other, we see sluggish, slow and most often neutral Old Believers, yielding to circumstances.

Secondly, a solely national interpretation of the conflict should be discarded. Many Belarusian and Lithuanian peasants were cut off from the rebels, from the gentry and the magnates who wanted to get rid of the Tsar's custody. For example, peasants (not Old Believers) of Mahilioŭ and Viciebsk provinces often turned in the insurgents to the authorities, which demonstrates the absence of any Belaruswide or Poland-wide solidarity. That is, in the first place there again class conflict took place, which turned out to be a weak point and one of the reasons for the defeat of the Uprising.

The fact that the Uprising was not widespread and was mostly supported by the nobility is not surprising. No uprising in those times in Europe showed solidarity among all social classes. Not only the Belarusian or Lithuanian but also the Scandinavian and French peasantry identified themselves primarily with the local land, and did not always consider themselves French, Norwegian or Swedish.

There was no solidarity between different layers (peasants, gentry, town-dwellers) of one nation, especially where it was divided on issues of religion and ideology and was as amorphous and immature as the Belarusian nation. There was no unified understanding of the nation, as there was no state in the first place. The chaotic, inconsistent participation of some representatives of local Old Believers along with Belarusian peasants in catching insurgents indicates that there was little or no communication among the various layers of society. This gives grounds to ideologically bind Westernrussists like Biendzin to claim that Kalinoŭski was not a supporter of the Belarusian idea, and that there was 'terror on behalf of the gentry' during the Uprising.

Speaking in terms of 'Belarusian' and 'Russian' at that time was not ideological, but even artificial. Most Belarusian peasants did not use the concept of 'Belarus', but all the while remained Belarusians in their nature. The initiative of naming this nation was given to the centre of the Empire. Historians like Biendzin look at the relationship between Belarusians and Russians through the prism of alleged equality and, in fact, the original oppression and subordination of Belarusians. This manipulation of the concept of 'Russians' or 'coming from Ruś' in relation to the Old Believers in Belarus in the nineteenth century is also incorrect, because the past cannot be labelled according to modern names. Ideology-driven historians safely allow themselves to break the limits of history and to attribute modern fea- 
tures to things from the past. Thus, the Old Believers who fled from Muscovy are drawn by them as the eternal 'Russian element', as Russians. But this is not true. The phantasms of ideology-driven historians are easily and constantly broken by such processes as merger and assimilation. Incidentally, it is reflected not only in numerous descriptions by ethnographers and travellers of the nineteenth century. It is also represented in statistics (Pervaia 1899; Pervaia 1901; Siementovskii 1864) which recorded data casting doubt on the assertions of russocentrist, Westernrussist thinkers and ideologues.

Third, the Old Believers' taking part in the Uprising on the side of the insurgents, or indeed their neutrality, are often completely ignored. Old Belief is treated as an actively hostile, anti-Belarusian element (Jaŭmienienka 2012; Vaĺtar 2009, 80-82; Doŭnar-Zapoĺski 1994, 222; Vaśkoŭ 2010). But a certain, albeit smaller, or even minor, part of the Old Believers in Belarus fought on the insurgents' side. The lists of participants in the 1863-1864 Uprising contain not only Polish, Belarusian and Lithuanian names and surnames, but also Jewish and Russian (Svodnyi spisok, 2014). Above all, modern historians based on the analysis of archives and photographs of that time claim there was a Russian, most likely Old Believers, element among the insurgents in 1863-1864 (Januškievič K., Januškievič J. 2013; Matvejčyk 2013, 66-77).

We should not forget the anti-Russian policy of Archbishop of Polack Vasil who not always, but at least during the Uprising, followed the line of the Sinod (Sobranie 1858, 689-690). If the authorities became more favourable towards the Old Believers, the archbishop during the Uprising reminded the Synod and the tsarist government about 'particular hostility of Viciebsk dissenters of both denominations' (Sobranie 1858, 689-690).

It all shows that the Old Believers in Viciebsk region were rather hostile to the authorities and the Orthodox Church, and treated them as 'a nest of vipers or ants, a Satanic home of demons' (Kratkoie 1853, 57) Certain manifestations of the Old Believers' solidarity with the tsarist authorities, pointed out by some historians and ethnographers, should be regarded as exceptions or simply private acts. However, ethnographic material of that time shows that relations between Old Believers and Belarusians developed peacefully and intensively in the vein of merger and spontaneous cultural cooperation. Their language, habits, customs, and way of working gradually mixed and blended, which also indicates that there were no conflicts between Old Believers and Belarusians in the majority of cases (Siementovskii 1872; Siementovskii 1864; Sapunov 1883; Nikiforovskii 1895; Marks 1995; Gorbachievskii 1895; Anikievich 1907).

One should regard the Uprising of 1863-1864 as a major breakdown, cut, and push (together with the revolt in 1830, the abolition of serfdom, and industrialization) 
that led to the formation of both the Belarusian and Russian nations. The Old Believers in those breakdowns fell on one and then on the other side of the nationbuilding process, depending on the degree of integration and assimilation in place. The example of Old Believers who arrived from the Muscovy but became 'local' as a result of merging and integrating shows that nations are not innate, but have a social, acquired, constructed basis. The local Old Believers have always been on the border between 'Russianness' and 'Belarusianness'. They combined these two models, and sometimes under the political imperial influence rejected one model in favour of the other.

The second point is the revision and analysis of the role of Old Believers in Belarus' nation-building process during the second half of the nineteenth century, activated by the 1863 Uprising. Through assimilation and integration into the historical Belarusian traditional community, many Old Believers were formed and evolved together with Belarusians. They formed an integral part of the future Belarusian nation. Thus, some of the Belarusian Old Believers naturally became part of the Belarusian nation at the time of its final formation. It may seem strange and complex, but the Belarusian nation was formed in the nineteenth century contrary to the policy of Russification of the imperial regime; and the process of nation-building involved a certain number of members of some other ethnic communities.

Ethnological reconstruction through the analysis of ethnographic works by Nikiforovskii, Anikievich, and Marks, and the statistical data of the time (Pervaia 1899; Pervaia 1901; Siementovskii 1872; Siementovskii 1864; Sapunov 1883; Nikiforovskii 1895; Marks 1995; Iwaniec 1977) suggests that a proportion of Old Believers in Belarus in the nineteenth century (between 10\% and 18\%) were integrated into the Belarusian ethnos and made part of the Belarusian nation. These are the terms used in the works of ethnographers and statistics at the end of the nineteenth century: the Old Believers - Belarusians, Belarusians - Old Believers, Old Believers-Belarusians from Viciebsk. Those terms are not mistakes or inaccuracies, as believed, for example, Jaŭchim Karski (1917) and later Antanina Zavaryna (1986). They are evidence of the processes of merging and integrating Old Believers and Belarusians. However, this trend covers not only the Old Believers in Belarus. For example, at the end of the nineteenth century in a nonSlavic Latvia, sometimes one could come across the term 'Latvian Old Believers' (Karski 1917; Zavarina 1986).

A cautious and critical appeal to the data of the First General Census of the Russian Empire gives us interesting figures: $18 \%-20 \%$ of Old Believers in Viciebsk, $45 \%$ of Old Believers in Nieviel district, $80 \%$ of Old Believers in Vieliž district, and generally about $22 \%$ of all Old Believers in Viciebsk province, 
recognized Belarusian as their native language (Pervaia 1899; Pervaia 1901). Even if we acknowledge the poor organisation of the First Census and inaccuracy in its results, a tendency towards the integration and a certain Belarusianization of Old Believers in the nineteenth century is nonetheless observed and described by many researchers.

Any consideration of the role played by Old Believers in the Uprising of 1863-1864 raises questions that can be somewhat difficult for historians to deal with if they strive to analyse the conflict in strictly national (Lithuanian, Belarusian, Russian) terms. At a time when Belarusians and Lithuanians had not yet formed political nations, the origins of the Uprising are to be sought more in questions of social class and religious allegiance, rather than in national yearnings. Questions of class and religion were ultimately the factors that ensured the defeat of the Uprising. Even so, the part played by Kalinoŭski through his military actions and his writings was a significant element in the nation-building process, bringing together a number of different peoples and groupings (Poles, Roma, Old Believers, Jews, Russians and Latgalians) in the nascent Belarusian nation. In the aftermath of the Uprising, tsarist policies were aimed at obstructing in every possible way the development of a Belarusian national and cultural movement. However, these policies yielded results that were at times quite unintended. The processes whereby Belarusians were merging with non-Belarusians - specifically, Old Believers with Belarusians, Latvians and Lithuanians changed radically: they actually sped up.

The Russian Empire had at its disposal vast informational, administrative and propaganda resources - notably the Russification policy in Belarus and the authorities' readiness to play the so-called 'Russian card' (i.e. the Old Believers) in order to weaken the resurgence of Belarusian national awareness. Nevertheless, by the end of the nineteenth century the nation-building process in Belarus had been completed. The development of capitalism in the Russian Empire as a whole - with its attendant features of urbanisation, industrialisation, schooling and the press - undoubtedly contributed a great deal to this process. Even so, the process had been accelerated much earlier by the Uprising of 1863 - an explosion of dissatisfaction among certain sections of the Belarusian, Lithuanian and Polish gentry classes at the lack of access to positions of real power in the Empire and their consequent inability to contribute to a solution of pressing social, economic and national problems. 


\section{References}

Alieksieiev, Leonid, 1974. Po zapadnoi Dvinie i Dniepru v Belorussii, Moscow: Iskusstvo.

Anikievich, K., 1907. Siennenskii uiezd Mogiliovskoi gubernii, Mogiliov: izdanie Mogilevskogo gubernskogo statisticheskogo komiteta.

Bendin, Alieksandr, 2013. Polsko-shliakhetskii terror i spisok ego zhertv vo vriemia pol'skogo vosstania 1863-1864 gg., <http://zapadrus.su/bibli/arhbib/781polsko-shlyakhetskij-terror-i-spisok-ego-zhertv-vo-vremya-polskogo-vosstaniya1863-1864-g-g.html> [accessed 21 October 2014].

Briezhgo, Boleslav, 1956. Ocherki po istorii kriest'ianskikh dvizhienii v Latgalii 1507-1907 gg., Riga: Izdatel'stvo Akademii nauk Latviiskoi SSR.

Dolbilov, Mikhail, 2010. Russkii krai, chiuzhaia viera: etnokonfessional'naia politika imperii v Litve i Belorussii pri Aleksandrie II, Moscow: Novoie literaturnoie obozrenie.

Doŭnar-Zapoĺski, Mitrafan, 1994. Historyja Bielarusi, Minsk: BelEn.

Gorbachievskii, Ivan, 1895. Liepielskii uiezd Vitebskoi gubernii, Viciebsk.

Grek-Pobisova, Irida, 1992. 'Iazyk kak svidietel'stvo izmenienii v zhizni staroobriadtsev poslie poselienia v Polshie', Acta Baltico-Slavica, 21, Warszawa.

Iwaniec, Eugeniusz, 1977. Z dziejów staroobrzędowców na ziemiach polskich $X V I I-X X$ w. Warszawa: PWN.

Ivanoŭ, Uladzislaŭ, 2008. 'Pra bielaruski ŭplyŭ na viciebskich staravieraŭ', Palityčnaja Sfiera, 10.

—, 2010. 'Evaliucyja tojesnasci i kuĺtury staravieraŭ paŭnočnaj Bielarusi: kaniec 19 - pačatak 21 st.', Palityčnaja Sfiera, 14.

Januškievič Kamila, Januškievič Jazep, 2014. Partrety paŭstannia, fotaaĺbom. Rakaŭ.

Jaŭmienienka, Viktar, 2012. 'Piataja kalona' u 1863, <http://arche.by/by/page/ science/historya-navuka/9082> [accessed 1 September 2014].

Karskii, Iefim, 1917. Etnograficheskaia karta belorusskogo pliemieni, Petrograd.

Korotkaia, Tatiana, Prokoshina, Iekaterina and Chudnikova, Anna, 1992. Staroobriadchestvo v Belarusi, Minsk: Navuka i tekhnika.

Kratkoie obozrenii sushchestvuiushchikh v Rossii raskolov, ieriesiei i sekt, kak v religioznom, tak i v politicheskom ikh znachienii, 1883. Sostavil Liprandi (1853 g.), Leipzig: E. L. Kasprovich. 
Leclère, Yvan. De la sédentarisation des nomades: Le cas des Vieux-Croyants du Nord-Ouest du début du XIX-ième siècle à la mort de Staline, <http://koebel. pagesperso-orange.fr/ActesI\&E/AXE3/leclere.html $>$ [accessed 1 August 2014].

Leclère, Yvan. Les Vieux-Croyants dans l'Estonie de l'entre-deux-guerres, $<$ http://ipr.univ-paris1.fr/spip.php?article85> [accessed 1 August 2014].

Leclère, Yvan. Naissance d'une nation? Les vieux-croyants du gouvernement général de Vilnius face au soulèvement lituano-polonais de 1863, < http://ipr.univparis1.fr/spip.php?article206> [accessed 1 August 2014].

Marks, Maksimilian, 1995. 'Zapiski starika', Viciebski sšytak, No.1.

Matvejčyk, Dzmitryj, 2013. 'Paŭstannie 1863-1864. Krynicy z Nacyjanaĺnaha histaryčnaha archiva Bielarusi', Archivy i spravavodstva, 1.

Nikiforovskii, Nikolai, 1895. Ocherki prostonarodnogo zhitia-bytia v Vitebskoi Belorussii i opisnie predmetov obikhodnosti, Vitebsk: Gubernskaia tipografia.

Pervaia vseobshchaia perepis' nasielienia Vitebskoi gubernii, Book 1, 1899, Saint Petersburg.

Pervaia vseobshchaia perepis' nasielienia Vitebskoi gubernii, Book 2, Table 13, 1901, Saint Petersburg.

Pivnieva, Ielena, 2001. 'Rabota Instituta etnologii i antropologii Rossiiskoi akademii nauk v 2000 g.', Etnograficheskoie obozrenie.

Potashenko, Grigorii, 2003. Russkie staroviery Polshi i Litvy v 1920-1930-kh gg (po materialam staroobriadcheskoi pechati), <http://www.russianresources.lt/ archive/Mater/Potash.html [accessed 11 September 2014].

—, 2006. Starovierie v Litve: vtoraia polovina 17-nachalo 19 vv. Issledovania, documenty i materialy. Vilnius: Aidai.

—, 2007. Staroviery Litvy: viekhi istorii (vtoraia polovina 17 -nachalo 21 vv.), part 1,<http://samstar-biblio.ucoz.ru/publ/52-1-0-74> [accessed 10 October 2014].

Praspaliauskiene, Rima. Women on Margins in Europe: 16th-20th Centuries, <http://web.ceu.hu/crc/Syllabi/alumni/gender/praspaliauskiene.html> [accessed 11 September 2014].

Sapunov, Aliaksei, 1883. Vitebskaia starina, Vol. 1, Vitebsk: Tipografia gubernskogo pravlenia.

Siementovskii, Alieksandr, 1872. Etnograficheskii obzor Vitebskoi gubernii, Saint Petersburg: Tipografia M. Khana.

—, 1864. Pamiatnaia knizhka Vitebskoi gubernii na 1864 god, Saint Petersburg. 
Sigma, G., O natsionalizme, <http://www.genocide.ru/lib/bhelp/i/i-72nationalism.html $>$ [accessed 11 September 2014].

Sobranie postanovlienii po chasti raskola, 1858, Saint Petersburg, pp. 689-690.

Svodnyi spisok uchasnikov vosstania 1863-1864 gg., <http://kdkv.narod.ru/1864/ Spis-A.htm $>$ [accessed 31 October 2014].

Tatarinov, Iurii, 1999. Puteshestvie v Sariu, Minsk: Minsktipproekt.

Vaśkoŭ, Uladzimir, 2010. Katoliki na abšarach Panizoǔja i Sievierščyny, Minsk: Pro Christo.

Vaĺtar, Viktar, 2009. Lieśnikova Siena. Selected Works, Minsk: Knihazbor.

Zavarina, Antonina, 1986. Russkoie naselienie vostochnoi Latvii vo vtoroi polovine 19 - nachalie 20 vieka, Riga. 